\title{
A Study of the Skin Absorption of Ethylbenzene in Man
}

\section{TADEUSZ DUTKIEWICZ and HALINA TYRAS}

\author{
From the Department of Toxicological Chemistry and Industrial Toxicology, Medical Academy, Lodz, Poland
}

The absorption of ethylbenzene through the skin of the hand and the forearm in men was investigated experimentally. Both the absorption of liquid ethylbenzene and the absorption from aqueous solutions were studied. The rate of absorption of liquid ethylbenzene was 22 to $33 \mathrm{mg} . / \mathrm{cm} .{ }^{2} / \mathrm{hr}$, and the rates from aqueous solutions were 118 and $215 \mu \mathrm{g} . / \mathrm{cm} .{ }^{2} / \mathrm{hr}$ from mean concentrations of 112 and $156 \mathrm{mg}$. $/$ litre.

The mandelic acid excreted in urine was equivalent to about $4.6 \%$ of the absorbed dose-much less than after lung absorption. Urinary mandelic acid does not provide a reliable index of absorption when there is simultaneous skin and lung exposure.

Ethylbenzene is used mainly as a source of styrene but is also a constituent of commercial aromatic solvents and of motor and aviation fuels. In recent years, the world production of ethylbenzene has increased steadily with a corresponding increase in the number of people occupationally exposed.

The most likely forms of exposure to ethylbenzene in industrial conditions are inhalation of vapours and mists and uptake via the skin after contact with the liquid. Skin uptake has not received much attention. No quantitative data concerning the skin absorption of ethylbenzene were found in accessible references. Most authors indicate that ethylbenzene may be absorbed through the skin in small amounts.

In the absence of quantitative data, the present investigation was undertaken to estimate the absorption of ethylbenzene through the skin in men.

\section{Methods}

\begin{abstract}
Absorption of Ethylbenzene The following procedure was adopted. A watch glass, $4.7 \mathrm{~cm}$. in diameter and $I \cdot 2 \mathrm{~cm}$. in depth, was tightly fixed to the skin of the forearm. Ethylbenzene (0.2 ml.; 0.1739 g.) was introduced with a syringe. After ro or $15 \mathrm{~min}$., I. $5 \mathrm{ml}$. of ethanol was introduced under the watch glass to dissolve the unabsorbed ethylbenzene. The solution in the watch glass was transferred with ethanol washings to a 25-ml. standard flask. The skin exposed was wiped with gauze, which was rinsed with ethanol. The rinsings were added to the standard flask. The concentrations of ethylbenzene were determined spectro-
\end{abstract}

Received for publication April 20, 1967. photometrically at $262 \mathrm{~m} \mu$ (Guertin and Gerarde, 1959; Bardoděj and Bardodějová, I966) using a Unicam SP-500 spectrophotometer. The amount of ethylbenzene absorbed was calculated from the difference between the applied and the remaining ethylbenzene. When the ethylbenzene was removed from the skin immediately after being placed in contact with it, recoveries averaged $99 \cdot 7 \%$.

Absorption of Ethylbenzene from Aqueous Solution Two methods were used, a direct method, similar in principle to that used above, and an indirect one, based on the excretion of mandelic acid, a metabolite.

Direct Method The whole hand was immersed for one hour in an aqueous solution of ethylbenzene of known concentration in a I-litre beaker. The concentrations of the solution were determined before and after, and the ethylbenzene absorbed was calculated by difference. The surface area of the hand was measured each time. Evaporation of ethylbenzene during the experiment was avoided by placing the beaker in a polythene bag which was fixed tightly to the beaker and to the skin of the forearm just above the wrist. In control experiments, it was shown that a solution protected in this way did not change its concentration in two hours. All experiments were carried out at 23 to $25^{\circ} \mathrm{C}$., maintained with a thermostat. Two initial concentrations of ethylbenzene were used-I5I mg./1. and $227 \mathrm{mg}$. $/ 1 .{ }^{1}$, corresponding to mean concentrations of $112 \mathrm{mg}$./1. and I56 mg./litre. The concentrations which could be chosen were limited by the solubility of ethylbenzene in water as well as by the sensitivity of the method for the determination of ethylbenzene. The volume of solution was chosen so as to ensure a decrease in concentration of

\footnotetext{
1slight emulsion.
} 
about $35 \%$ during the experiment. Under these conditions the changes in concentration during an experiment were sufficiently marked, but the decrease in concentration did not much alter the absorption. The concentrations of aqueous solutions were estimated as before in relation to a reference solution. This was distilled water in which the other hand of the exposed person had been immersed for one hour. It absorbed at $262 \mathrm{~m} \mu$ slightly more than pure distilled water.

Concentrations were also determined after transfer from water in an air stream by a nitration method. The methods agreed well with each other.

Indirect Method The hands were exposed as before, but, to obtain more metabolite, both hands were exposed in each experiment, and for two hours, not one hour. Urine samples were collected every two hours during 14 hours from the beginning of the exposure, and another Io hours later. The main metabolite of ethylbenzene, mandelic acid (Bardoděj and Bardodějová, 1966), was determined in urine by a polarographic method as described by Bardoděj and Bardodějová (I96I) and Bardoděj, Fišerová-Bergerová, and Ledrer (I964).

Determination of Ethylbenzene in the Expired Air Some attempts were made to estimate ethylbenzene in expired air. Samples of air were taken during exposure to liquid ethylbenzene and three hours later. The expired air was blown at $51 . / 15 \mathrm{~min}$. through two bubblers in series each containing $2 \mathrm{ml}$. of nitrating mixture.

\section{Results}

Seven determinations of liquid ethylbenzene skin absorption in seven men were carried out (Table I). The absorption rates varied from 22 to $33 \mathrm{mg} . / \mathrm{cm} .{ }^{2} /$ hr.

Ethylbenzene absorption from aqueous solution was estimated on seven subjects in 14 experiments, six on one subject (H.T.) (Table II). The rates of

TABLE I

Liquid Ethylbenzene Absorption through the SkIN

\begin{tabular}{|c|c|c|c|c|c|}
\hline No. & $\begin{array}{l}\text { Sub- } \\
\text { ject }\end{array}$ & $\begin{array}{c}E x- \\
\text { posed } \\
\text { Area } \\
\left(\mathrm{cm}^{2}\right)\end{array}$ & $\begin{array}{c}\text { Time of } \\
\text { Ex- } \\
\text { posure } \\
\text { (Min.) }\end{array}$ & $\begin{array}{l}\text { Absorbed } \\
\text { Ethyl- } \\
\text { benzene } \\
\text { (mg.) }\end{array}$ & $\begin{array}{c}\text { Absorption } \\
\text { Rate } \\
\left.\text { (mg./cm. }{ }^{2} / \mathrm{hr}\right)\end{array}$ \\
\hline I & F.N. & $17 \cdot 3$ & IO & $93 \cdot 2$ & 32 \\
\hline 2 & M.O. & $17 \cdot 3$ & 10 & $96 \cdot 0$ & 33 \\
\hline 3 & J.K. & $17 \cdot 3$ & IO & 93.0 & 32 \\
\hline 4 & W.K. & $17 \cdot 3$ & I5 & 110.6 & 25 \\
\hline 5 & H.T. & $17 \cdot 3$ & I5 & $104 \cdot I$ & 24 \\
\hline 5 & A.P. & $17 \cdot 3$ & IO & $64 \cdot I$ & 22 \\
\hline 7 & S.A. & $17 \cdot 3$ & I5 & $130 \cdot 0$ & 30 \\
\hline
\end{tabular}

Mean rate of absorption $\quad 28$
TABLE II

Ethylbenzene Absorption fRom AQUeous Solutions (DIRECT MeThoD)

\begin{tabular}{|c|c|c|c|c|}
\hline No. & Subject & $\begin{array}{c}\text { Mean Conc. } \\
\text { Ethylbenzene } \\
(\text { mg./l. })\end{array}$ & $\begin{array}{c}\text { Absorbed } \\
\text { Ethylbenzene } \\
\text { (mg.) }\end{array}$ & $\begin{array}{c}\text { Absorption } \\
\text { Rate } \\
\left(\mu g \cdot / c m .^{2} / h r\right)\end{array}$ \\
\hline $\mathbf{I}$ & H.T. & $112 \cdot 7$ & $38 \cdot 5$ & 120 \\
\hline 2 & H.T. & I I 3.1 & $38 \cdot 1$ & I19 \\
\hline 3 & I.M. & I IO. I & $4 I \cdot I$ & 128 \\
\hline 4 & F.N. & $109 \cdot 3$ & $41 \cdot 9$ & I2I \\
\hline 5 & M.O. & $113 \cdot 1$ & $38 \cdot 1$ & 109 \\
\hline 6 & J.K. & I I I 6 & $39 \cdot 6$ & I 16 \\
\hline 7 & H.T. & 113.9 & $37 \cdot 3$ & 116 \\
\hline \multicolumn{2}{|c|}{ Average } & I $12 \cdot 0$ & $39 \cdot 2$ & 118 \\
\hline 8 & J.Kd. & I $54^{\circ}$ I & $72 \cdot 8$ & 214 \\
\hline 9 & A.B. & $162 \cdot 0$ & $64 \cdot 4$ & 201 \\
\hline IO & H.T. & I 54.8 & $72 \cdot I$ & 225 \\
\hline I I & A.B. & $160 \cdot 0$ & $66 \cdot 8$ & 208 \\
\hline 12 & H.T. & 155.5 & $7 I \cdot 4$ & 223 \\
\hline I3 & H.T. & 159.3 & $67 \cdot 2$ & 210 \\
\hline I4 & F.N. & $147 \cdot 5$ & $80 \cdot 3$ & 229 \\
\hline \multicolumn{2}{|c|}{ Means } & $156 \cdot 2$ & $70 \cdot 7$ & $215 \cdot 7$ \\
\hline
\end{tabular}

TABLE III

ETHYLBENZENE ABSORPTION FROM AQUBOUS SOlutions USING THE INDIRECT METHOD (TIME OF EXPOSURE 2 HOURS)

\begin{tabular}{|c|c|c|c|c|c|}
\hline \multirow{2}{*}{ No. } & \multirow{2}{*}{ Subject } & \multirow{2}{*}{$\begin{array}{c}\text { Absorbed } \\
\text { Ethyl- } \\
\text { benzene } \\
\text { by Direct } \\
\text { Method } \\
\text { (mg.) }\end{array}$} & \multirow{2}{*}{$\begin{array}{c}\text { Absorption } \\
\text { Rate } \\
\left(\mu g \cdot / \mathrm{cm}^{2} / \mathrm{hr}\right)\end{array}$} & \multicolumn{2}{|c|}{$\begin{array}{c}\text { Excreted Mandelic } \\
\text { Acid }\end{array}$} \\
\hline & & & & $\begin{array}{c}\text { During } \\
24 \text { hrs } \\
\text { (mg.) }\end{array}$ & $\begin{array}{c}\text { Percentage } \\
\text { of } \\
\text { Absorbed } \\
\text { Dose }\end{array}$ \\
\hline $\begin{array}{l}1 \\
2 \\
3 \\
4 \\
5\end{array}$ & $\begin{array}{l}\text { H.T. } \\
\text { B.A. } \\
\text { T.K. } \\
\text { M.O. } \\
\text { F.N. }\end{array}$ & $\begin{array}{l}250 \\
241 \\
235 \\
252 \\
259\end{array}$ & $\begin{array}{l}195 \\
186 \\
174 \\
199 \\
193\end{array}$ & $\begin{array}{l}12.39 \\
20.62 \\
18.42 \\
16.42 \\
13.54\end{array}$ & $\begin{array}{l}3.46 \\
5.97 \\
5.46 \\
4.55 \\
3.65\end{array}$ \\
\hline \multicolumn{2}{|c|}{ Average } & $247^{\circ} 4$ & $189 \cdot 4$ & $16 \cdot 28$ & $4 \cdot 6 I$ \\
\hline
\end{tabular}

absorption were calculated taking into consideration the area of the hand in each case.

A further five experiments on absorption from aqueous solution were carried out on five men using the indirect method. The applied initial concentration of ethylbenzene amounted to 227 mg./1., and corresponding mean concentrations amounted to mean $142 \mathrm{mg}$./litre. The results are shown in Table III and the Figure. In 24 hours the mandelic acid excreted was equivalent to $4 \cdot 6 \%$ of 


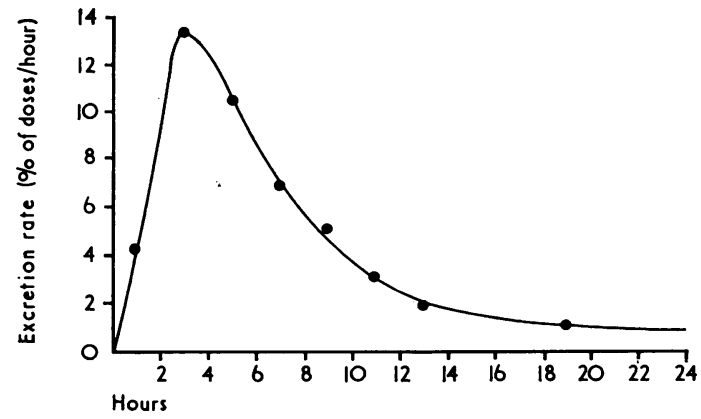

FIGURE Mandelic acid excretion in urine after skin absorption of ethylbenzene (mean data from five experiments).

the absorbed ethylbenzene. No ethylbenzene was excreted in the exhaled air when about $250 \mathrm{mg}$. of ethylbenzene was absorbed.

\section{Discussion and Conclusions}

It was found that the rate of absorption of liquid ethylbenzene by the hand was 22 to $33 \mathrm{mg} . / \mathrm{cm} .^{2} / \mathrm{hr}$, whereas from aqueous solutions the rates were 118 and $215 \mu \mathrm{g} . / \mathrm{cm} .{ }^{2} / \mathrm{hr}$ for the mean concentrations of ethylbenzene of II2 mg./1. and $156 \mathrm{mg}$. $/ 1$. respectively. Thus the absorption of ethylbenzene through the skin in men is very rapid for both the liquid ethylbenzene and its aqueous solutions.

\section{TABLE IV}

Comparative Data For the Rates of Absorption THROUGH THE SkIN OF TOXIC SUBSTANCES

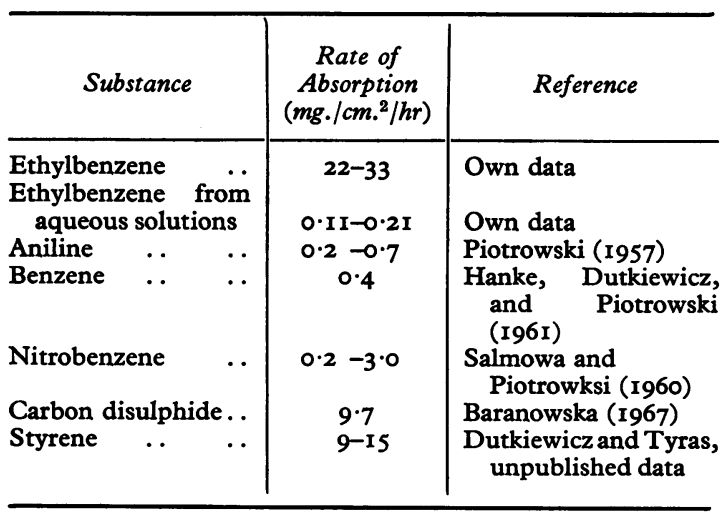

The rates are compared with those of other toxic substances in Table IV. The absorption rate of ethylbenzene through the skin is much higher than the rates of absorption of other toxic substances. Compared with its absorption through the respiratory system, skin absorption could be the major route of penetration into the body. Thus exposure of two hands to saturated ethylbenzene solution for two hours or to liquid ethylbenzene for only one minute would lead to the absorption of as much ethylbenzene as would be taken up by the lungs from eight hours' exposure to the M.A.C. ${ }^{1}$ of O. I mg./litre.

Bardoděj and Bardodějová (1966) showed that, of ethylbenzene absorbed through the lungs, about $60 \%$ was excreted in urine as mandelic acid. After skin absorption the metabolism of ethylbenzene in the body is different. The excretion of mandelic acid in urine is much less, amounting only to $4.6 \%$ of absorbed ethylbenzene. Differences in the metabolic fate of compounds after lung and skin absorption have also been demonstrated for carbon disulphide (Baranowska, 1965) and styrene (Dutkiewicz and Tyras, unpublished data).

The determination of mandelic acid excretion in urine was recommended as an exposure test for ethylbenzene (Bardoděj and Bardodějová, 1966). In view of our investigations this would not be a reliable index of the ethylbenzene absorption for simultaneous exposure to vapour and to skin contamination.

\section{REFERENCES}

Baranowska, B. (1965). Symposium on Industrial Toxicology of Socialist States, 8, 12, Lódź, Poland.

- (1967). A study of absorption of carbon disulphide through the skin in men. Ph.D. thesis, p. 38. Lódź, Poland.

Bardoděj, Z., and Bardodějová, E. (I96I). Cs. Hyg., 6, 537.

,-- (1966). Ibid., 11, 226.

—, Fišerová-Bergerová, V., and Ledrer, E. (1964). Pracov. Lék., I6, 4I4.

Guertin, D. L., and Gerarde, H. W. (1959). Arch. industr. Hlth, 20, 262.

Hanke, J., Dutkiewicz, T., and Piotrowski, J. (196I). Med. Pracy, 12, 413.

Piotrowski, J. (1957). F. Hyg. Epidem. (Praha), 1, 23.

Salmowa, J., and Piotrowski, J. (1960). Med. Pracy, Ir, I.

${ }^{1}$ The M.A.C. for ethylbenzene accepted in Poland (Orders of Ministry Council, August 21, 1959) is $0.1 \mathrm{mg}$./litre. This is equivalent to 23.07 parts per million. 